\title{
THE IMPACT OF NEW PUBLIC MANAGEMENT REFORMS ON PUBLIC SERVANTS' ETHICS: TOWARDS A THEORY
}

\author{
JEROEN MAESSCHALCK
}

Recent years have witnessed an increasing concern about the impact of New Public Management (NPM) reforms on public servants' ethics. The academic literature about this topic is still characterized by considerable confusion and the article proposes a falsifiable theory as a way out of this. Specifically, it demonstrates that, when all the claims in the literature are translated into the proposed conceptual framework, they amount to an integrated set of propositions (that is, a theory) about the causal relationship between organizational processes (as changed by NPM-reforms) and public servants' ethics. Such an integrated theory is possible because, although the normative positions taken by the authors are clearly rival ones, their empirical claims are complementary. With the diverse claims thus integrated into one theory, the article provides a basis for empirical research and for the NPM-ethics debate to proceed in a more explicit and systematic way.

\section{INTRODUCTION}

There is a growing sense among the public in western democracies as well as among some public administration scholars (Chapman 1994; Chapman and O'Toole 1995; Frederickson 1999) that corruption by public servants is increasing. Others express doubts about such an increase (for example, Gilman 1999), but both the academic public administration literature (for example, Van Wart 1998; Hondeghem 1998; Van Wart and Berman 1999) and the more practice-oriented literature (for example, OECD 1996, 2000) seem to agree that there is a significant shift in public service ethical standards and, subsequently, in (un)ethical behaviour.

Many of those seeking to account for this shift refer to various aspects of the recent changes in the public sector that have come to be known as public management reform in general (maintain, modernize, marketize, minimize; see Bouckaert and Pollitt (2000)) and 'New Public Management' (NPM) more specifically. NPM, to say the least, is a highly contested concept. It refers to reforms that have become popular in many OECD countries during the 1980s and 1990s of the previous century. These reforms included quangotization, the introduction of performance management systems, more responsibility and accountability for public managers, more competition in the public sector, the introduction of quality management techniques, and

Jeroen Maesschalck is Senior Researcher at the Public Management Institute of the Katholieke Universiteit Leuven. 
so on (Hood 1991, 1994; Bouckaert and Pollitt 2000). The term NPM has been coined by Christopher Hood $(1991,1994)$ who conceived of it as a set of administrative doctrines, that is, 'specific ideas about what should be done in administration' (Hood and Jackson 1991, p. 12). These doctrines amount, according to Hood, to an administrative philosophy that has come to be widely accepted.

The apprehension for the potentially negative impact of these reforms on the ethics of public servants has been strengthened by highly publicized scandals in many OECD countries. Many of these examples are about individuals behaving unethically and often also illegally and causing their public sector organization financial and other difficulties, for example, Robert Citron in Orange County, California (Cohen and Eimicke 1999) or George Brouwer in the Dutch Province of South Holland (Yesilkagit and de Vries 2002). The assumption is that the NPM-type rhetoric and reforms provided these individuals not only with the opportunity to do this but also with the moral mindset to justify it. NPM-type reforms are also alleged to lead to more collective or even systemic unethical behaviour. A case in point are the perverse effects of performance management systems. Van Reeth (2002, referring to US Senate (1991, p. 119)), for example, reports that the direct link between outcome measures and resource allocation in the Employment and Training Administration of the US Department of Labor had produced 'creaming strategies' such as focusing training on the most job-ready applicants.

The answer of public administration scholars to these scandals and to the more general concerns about the impact of the reforms on (un)ethical behaviour of public servants is very diverse. Roughly summarized, the literature about the impact of NPM-reforms on the ethics of public servants (henceforth 'the NPM-ethics' literature) consists of four rival positions, each proposing their own administrative doctrines for ethics management in the public sector. Three of these positions are rooted in a broader administrative philosophy in the sense of Hood and Jackson (1991).

The first position is anchored in the NPM administrative philosophy. Sometimes NPM-proponents emphasize how competition mechanisms can reduce corruption, for example, by lessening the opportunities of public servants to corruptly charge monopoly rents (Klitgaart 1988, p. 43). More often, however, they remain silent on the topic of ethics (Menzel 2000). The assumption seems to be that ethical behaviour will naturally follow from an implementation of NPM-reforms. Ethical behaviour is then mainly understood as behaviour that strengthens 'the three E's' (economy, efficiency and effectiveness).

The second position is at the other side of the spectrum. It is rooted in 'Traditional Public Administration' (TPA), also referred to as the 'old public administration' (Denhardt and Denhardt 2000) or the 'orthodox model' (Fox 2001, p. 109). The basic administrative doctrine of TPA with regards to ethics management prescribes that the organizational processes be organized in such a way that 'the individual ethical choice is limited to choosing to follow 
the rules (the ethical thing to do) or to violate them by commission or omission (unethical acts)' (Fox 2001, p. 110). In the NPM-ethics debate the proponents of TPA have, according to one observer, 'throw[n] up their hands in horror at recent trends, seeing them as marking the destruction of the public service ethos' (Greenaway 1995). Greenaway himself refers to Chapman and O'Toole (Chapman 1994, 1998; Chapman and O'Toole 1995) for the UK, who express 'a traditional view in a period of change' (Chapman and O'Toole 1995) and argue for a return to the traditional civil service ethos and to the traditional concept of 'public duty' (ibid., p. 11). Writing from the US context, Frederickson $(1993,1997,1999)$ also forcefully expresses his concerns about the ethical consequences of NPM innovations such as marketizing, privatizing or contracting-out and he argues for a 're-regulation' (Frederickson 1999, p. 276). One particularly prominent strand in the TPAtradition emphasizes the legal point of view and criticizes NPM 'for its sometimes cavalier treatment of the rule of law, especially its free and easy slogans about eliminating red tape and letting managers manage' (Rohr 2002, p. xi) (see, for example, Newland 1994; Moe and Gilmour 1995; Cooper 2000; Rosenbloom, Carroll and Carroll 2000).

The third position is derived from what has recently been labelled the 'New Public Service' (NPS) (Denhardt and Denhardt 2000). Skidmore (1995) describes a similar approach as the 'classical' or 'Aristotelian' mode of organizing (referring to its roots in MacIntyre's work), while others (for example, Fox and Miller 1996) have labelled this the 'communitarian/citizen alternative.' Denhardt and Denhardt (2000) present the NPS approach as a viable third alternative for the observed dichotomy between 'the old public administration' and 'the New Public Management'. Rather than traditional bureaucracies that are controlled from the top down and largely closed for citizens, Denhardt and Denhardt (2000) propose new mechanisms in which 'the primary role of the public servant is to help citizens articulate and meet their shared interests rather than to attempt to control or steer society' (p. 549). They build inter alia on the communitarian tradition, which has acquired a strong position in public administration through the work of Terry Cooper (see the review of Fox (2001, p. 122)). As for the NPM-ethics debate, those writing from a NPS point of view largely join the TPA-advocates in their negative assessment of the ethical consequences of NPMreforms, but propose a different solution. Again, Denhardt and Denhardt (2000) summarize the argument. They argue that public sector organizations should be organized in such a way that public servants are not responsive to 'constituents and clients' (TPA), nor to 'customers' (NPM), but to 'citizens'. Several other authors have criticized NPM from a NPS point of view. Although he also used TPA-arguments to criticize NPM, most of Frederickson's prescriptive claims (particularly in The Spirit of Public Administration (1997)) rather correspond to the NPS administrative philosophy. One example of this is his plea for a 'combination of patriotism (the love of the regime values) with benevolence (the love of others)' (p. 202). Gawthrop (1998) fits 
the NPS philosophy even more neatly. He contrasts the 'democratic spirit' with the NPM-type 'entrepreneurial spirit' and emphasizes that the former should prevail. He also strongly criticizes the TPA-type 'ethics of compliance' that he observed in US public administration over the past five decades (p. 153) for leading to a soulless public administration, obsessed with procedural correctness. He argues that public servants should have a personal responsibility, with 'service as the centre of value' (p. 80). The choice for a career as public servant implies 'opting for a career of service to the public, to the citizenry, to one's neighbours' (p. 23).

The fourth position in the debate does not clearly build on a single identifiable administrative philosophy like the previous three. Its central argument is that public sector ethics management is an important and evolving subfield of public management, which deserves its own set of doctrines, hence the 'Ethics Management' approach. Its core doctrine is that an ethics policy should be a combination of doctrines from the three aforementioned approaches, adapted to the specific circumstances of the organization. Admittedly, arguments for a combination of different approaches have been articulated before. Cooper, for example, proposed such a combined approach in his seminal The Responsible Administrator (1st edn, 1982). However, the success of the NPM-discourse and the concomitant ethical concerns fostered a recent revival of this approach. The Public Management (PUMA) department of the OECD $(1996,2000)$ has been among its most prominent promoters, together with practice-oriented academics such as Gilman (1999) or Uhr (1999). These and other recent proponents agree with the NPMadvocates that NPM-reforms can have many beneficial consequences, but are at the same time conscious of the undesirable effects (that is, unethical behaviour). However, in contrast with TPA and NPS, their solution is not to do away with NPM innovations, but to complement them with a welldeveloped public sector ethics management that is adapted to the reforms. They see two possible approaches to such an ethics policy: the compliance or 'low road' (Rohr 1978) and the integrity or 'high road' (ibid.) approach. The former 'focuses on strict compliance with descriptive administrative procedures, control mechanisms and detailed rules (... ') (OECD 2000, p. 25), and hence comes very close to the ethics management doctrines of TPA. The 'Ethics Management' proponents observe, however, that this compliance approach does not fit the NPM-style results-based managerial approach. It thus violates their basic doctrine of a management style adapted to the circumstances. Instead, NPM-type changes need to be complemented by an 'integrity' approach to ethics management that is 'based on aspirations, relies on incentives and encourages good behaviour rather than policing and punishing errors and wrongdoing' (ibid.). This claim is warranted on the ground that the increased discretion that goes with the reduction of hierarchy in NPM-reforms needs to be paralleled by an ethics management style that supports the public servants in dealing with this discretion, rather than limiting their discretion by developing new rules and control systems. 
This fourfold answer offered by the public administration literature remains rather unsatisfying. A public administrationist who consider implementing NPM-reforms, while at the same time wanting to avoid undesirable ethical consequences, is probably even more confused after reading through this literature. Who should he or she believe? The participants in the debate do make use of examples to support their claims. Yet, when all these claims are put together, they turn out to be quite contradictory, formulated in very different languages and traditions and without much systematic referencing to each other. At least three reasons can account for these limitations in the NPM-ethics literature. First, a large part of these texts feature in a broader debate 'for or against' NPM, which often blurs the distinction between the authors' empirical and normative claims where these could have been separated. Second, the issue of the ethical consequences of NPM only really surfaced when the NPM-reforms were introduced, in countries like the US, the UK, Australia or New Zealand. Hence, this 'area' of research is young, which accounts for the limited systematic work that has been done hitherto. Similarly, in the literature on the causes of NPM, it took some time for conceptual clarity to emerge (Barzelay 2001). Finally, possibly even more than other public administration issues, this issue really rests on the crossing points of very diverse theoretical traditions, ranging from organization theory (for example, the organization culture literature) through political science and public administration to moral philosophy. This as well helps to account for the conceptual confusion.

With this conceptual disarray in mind, and at this point of the debate, it is more important to aim for a coherent theory than to provide yet another set of examples that supports any of the empirical claims made in the literature. Specifically, this article's aim is to suggest a solution for the conceptual confusion and to develop a falsifiable theory about the causal relationship between NPM-reforms and the ethics of public servants. This theory is intended to provide the framework for further empirical testing of the claims in the literature. Hence, it intends to encompass the claims in the literature, while still being coherent. I will argue that such an integrated theory is possible because, although the normative positions taken by the authors are clearly rival, their empirical claims are complementary. This argument will be developed in three steps. First, a conceptual framework will be presented, into which the diverse claims in the literature can later be translated. Since the eventual theory will have to be testable, this conceptual framework will use existing typologies that have proven to be empirically meaningful and useful. The second section will then bring this conceptual framework to life, by developing it into a theory, that is, a set of falsifiable empirical propositions. With the conceptual framework consisting of typologies, those propositions will link particular types with each other. The theoretical foundation for this theory will be 'cultural theory' or 'grid-group theory' as developed by Thompson, Ellis and Wildavsky (1990). The third section will then link the proposed conceptual framework and theory with 
the NPM-ethics literature. It will particularly be shown that, when the claims made in the NPM-ethics literature are translated into the language of the conceptual framework, they parallel the propositions of the presented theory. With the diverse claims thus translated into one conceptual framework and integrated into one theory, the ambition of the article is to provide a framework for empirical research and, more generally, for the NPM-ethics discussion to proceed in a more explicit and systematic way.

\section{PROPOSING A CONCEPTUAL FRAMEWORK}

As mentioned above, the authors in the NPM-ethics literature do not simply present their administrative doctrines, but also provide justifications, consisting of empirical claims. Essentially they argue that their favourite doctrines lead to ethical decision making, while the doctrines they disapprove of foster unethical behaviour. This section aims to present a conceptual framework that is able to bring these diverse claims together.

The core variables of the conceptual framework are presented in figure 1. This framework is inspired by Vidaver-Cohen (1998), but significantly departs from it. The relationship between the core variables can be summarized as follows. Organizational processes are organizational stimuli that 'signal' (Vidaver-Cohen 1998) expectations for ethical decision making and unethical behaviour. Ethical decision making and unethical behaviour are a response to these stimuli. The individual variables and the environment are included in the framework as control variables but are not the main focus of interest. The framework and the theory that will be based on it (see below) assume a reciprocal causal relationship between these variables, as expressed through the bi-directional arrows in figure 1 (and later in table 3). The NPMethics literature, emphasizing the impact of the organization on public servants' ethics, focuses on one direction and so does the title of the present article. An expansion of this towards reciprocal causality is feasible, however. To mention just one example of a causal effect in the other direction, organizations might learn from particular instances of unethical behaviour

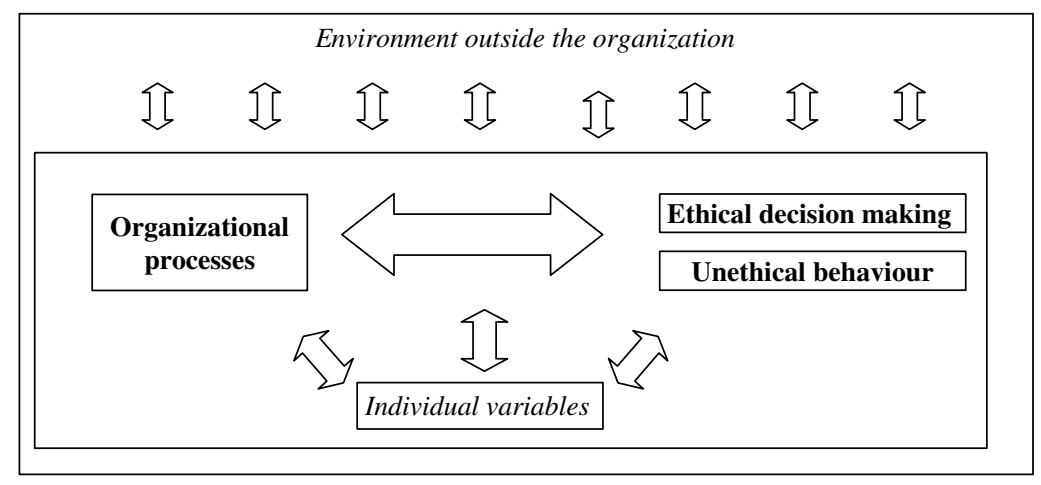

FIGURE 1 Conceptual framework 
('ethics failures' (see Zajac 1996)), and adapt their organizational processes. The following subsections will now briefly operationalize each of the main elements of the conceptual framework: organizational processes, ethical decision making, and unethical behaviour.

\section{Organizational processes}

Those arguing against NPM propose their own alternative for it. Hence,

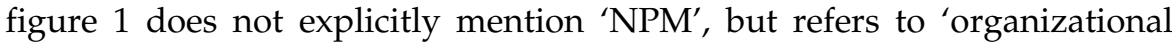
processes' in a more general sense. These 'organizational processes' organize the interactions in an organization in a particular way. Three 'types of interaction patterns' are distinguished: hierarchy, individualism and egalitarianism. This typology is essentially based on the 'grid-group theory' or 'cultural theory' that was developed by the anthropologist Mary Douglas (1978) and later applied to political science (Thompson, Ellis and Wildavsky 1990) and to public management (Dunleavy and Hood 1994; Hood 1998). Central to the theory are the types, which have been conceived of as 'cultural biases', 'cosmologies', 'ways of organizing', etc. For our purposes we conceive of them as 'interaction patterns' and concentrate on the three 'active' types, which broadly correspond to the types of other classic typologies (for example, Ouchi (1980), Petrick and Quinn (1997) and Hirschman (1970)). The discussion will thus exclude grid-group theory's fourth and 'passive' interaction type 'fatalism'. For although it is important as an empirical category, it is not endorsed or defended by any of the authors in the prescriptive NPM-ethics literature.

Typical for the hierarchist interaction pattern is the strong emphasis on classifications, roles, rules and procedures: 'individuals in this social context are subject to both the control of other members in the group and the demands of socially imposed roles. (...) The exercise of authority (and inequality more generally) is justified on the grounds that different roles for different people enable people to live together more harmoniously than alternative arrangements' (Thompson et al. 1990, p. 6). This is the preferred interaction pattern of the advocates of the Traditional Public Administration administrative philosophy. The egalitarian interaction pattern, on the other hand, emphasizes the boundaries of the group and aims at equality within the group, 'not equality of material conditions but equality of power relations. No one, in an egalitarian way of life, has the right to tell another what to do or what to be' (ibid., pp. 156-7). The administrative doctrines of the New Public Service philosophy demonstrate a strong preference for this egalitarian interaction type. Third, the individualist interaction pattern creates a strongly competitive environment in which power relations will differ, not because of tradition or formal organization as in hierarchy, but as a consequence of the constant competition. This interaction pattern is preferred by the NPM-adherents.

Thus, although more developed versions of each of the three administrative philosophies do consider several interaction types, they each have a clear preference for one particular type. Only the fourth approach 
mentioned above explicitly combines the three interaction patterns: the ethics management approach presents the compliance (hierarchist) and integrity (egalitarian) approaches to ethics management as complements for the existing and generally accepted NPM-measures (individualism).

\section{Public sector ethics}

Having defined organizational processes, we can now turn to the other side of the arrow: the ethics of public servants. This is operationalized as 'ethical decision making' and 'unethical behaviour' (rather than, for example, 'ethical and unethical decision making' or 'ethical and unethical behaviour') because this parallels the usual operationalizations in the organizational ethics literature and in the NPM-ethics literatures. As for the former, there is a strong tradition of empirical research into both 'ethical decision making' (see for example Fritzsche and Becker 1984; Trevino 1986; Hunt and Vazquez-Parraga 1993; Stewart and Sprinthall 1993; Sims and Keon 1999; Stewart et al. 2001) and 'unethical behaviour' (see for example Akaah 1992; McNeil and Peachment 1996; Kaptein 1998). Specifically, both variables will be operationalized by means of a typology that has been used and tested extensively in the organizational ethics literature (for a recent overview, see Agarwal and Malloy 1999). Using this existing typology allows for an empirically sound operationalization of the variables and thus facilitates future empirical testing of the propositions.

\section{Ethical decision making}

The conceptualization of ethical decision making is based on the typology that was developed by Victor and Cullen $(1987,1988)$ to describe different 'ethical climates'. Here, it is not used to classify ethical climates, but to classify 'ethical standards', that is, prescriptions about the way public servants should reason in ethical situations. The theoretical typology of Victor and Cullen (see table 1) has two dimensions, each with three positions. The dimension 'ethical criterion' refers to three major classes of ethical theory that can also be found in Kohlberg's widely known theory of moral development (see for example Kohlberg 1984; Stewart, Sprinthall and Shafer 2001): egoism, benevolence and principle. The dimension 'locus of analysis' refers to the main referent group that identifies 'the source of moral reasoning used for applying ethical criteria to organisational decisions and/or the limits on what would be considered in ethical analyses of organisational decisions' (Victor and Cullen 1988, p. 105). The individual locus of analysis identifies the sources of ethical reasoning within the individual. The local locus of analysis identifies sources of ethical reasoning at the level of the organization. The cosmopolitan locus locates the referent for ethical reasoning outside the organization. Together, the ethical criterion dimension and the locus of analysis dimension identify nine ethical standards. The nine types in table 1 are largely based on the typology of Victor and Cullen, but their definition is somewhat adapted to the public sector and to the purposes of this conceptual framework. 
TABLE 1 Nine ethical standards

\begin{tabular}{|c|c|c|c|}
\hline $\begin{array}{l}\text { Locus of analysis/ } \\
\text { ethical criterion }\end{array}$ & Individual & Local & Cosmopolitan \\
\hline Egoism & Self-interest & $\begin{array}{r}\text { Organizational interest } \\
\text { (2) }\end{array}$ & Efficiency \\
\hline Benevolence & Friendship & Team interest & Stakeholder orientation \\
\hline Principle & $\begin{array}{l}\text { Personal morality } \\
\text { (7) }\end{array}$ & Organizational rules & Laws and public interest \\
\hline
\end{tabular}

Source: adapted from Victor and Cullen 1988, with permission.

The 'egoism criterion' is focused on maximizing self-interest, which is defined in a narrow, instrumental and economic sense of immediate interest. The loci of analysis identify the particular 'self' of which the interests are maximized: the individual, the organization and society. Each of them is considered as 'a reified, indivisible unit that can be understood to have needs and preferences' (Victor and Cullen 1988, pp. 106-7).

Those who apply the 'benevolence criterion' on the other hand, typically make teleological considerations of the consequences of their actions. People applying this criterion do not think of themselves as being part of a single, reified self of which the interests should be maximized, but they make a distinction between the subject and the object of ethical behaviour and consider the consequences of their behaviour for the well-being of others. The locus of analysis identifies the relevant object of these considerations. When applying the 'friendship' standard, people consider other people without any reference to organizational membership. At the local level, the benevolence criterion is defined as 'consideration of the organisational collective (e.g. esprits de corps, team play)' (ibid., p. 107): the team interest standard. At the cosmopolitan level people consider the consequences of their actions for stakeholders outside the organization. Public servants applying this 'stakeholder orientation' standard in moral reasoning consider the consequences of their actions for their clients as far as they can conceive of these. They will not consider the consequences of their actions for inconceivable and 'intangible' groups such as 'the electorate', 'the taxpayers' or 'the wider public'.

People applying the 'principle criterion' make a deontological consideration of laws, rules and principles when dealing with ethical issues. The loci of analysis then identify the sources from which the principles can be derived. At the individual level, the personal morality standard prescribes that people in an organization follow their own principles and rules when they are confronted with an ethical problem. At the local level, the source of the principles lies within the organization. This is the typical rule-following standard that is often assumed to dominate in classical bureaucratic organizations. At the cosmopolitan locus, the source of the principles is outside the immediate 
organization. This standard prescribes that people refer to extra-organizational sources to justify ethically sensitive decisions. These include laws and codes but also general principles such as justice, equity, neutrality, and so on. For this reason, in table 1, cell 9, 'public interest' is mentioned specifically.

\section{Unethical behaviour}

'Ethical decision making' refers to complex and difficult ethical dilemma situations where people usually perceive it to be very difficult to judge what ethical behaviour is. The second subvariable 'unethical behaviour' refers to behaviour that most people would reasonably judge to be unethical. Obviously, 'unethical behaviour' is a very ambiguous term that leaves much scope for bias. Rather than trying to completely avoid bias, this conceptual framework makes it explicit by defining 'unethical behaviour' as 'the excessive use of one of the nine ethical standards'. In other words, it refers to a too radical (and therefore misunderstood) application of this standard. In table 2, I have reframed the criteria in Victor and Cullen (1988 - see table 1, above), to provide descriptions of the excessive use of the corresponding standards.

The first line in table 2 refers to the three types of unethical behaviour in which self-interest is maximized. The unethical behaviour on the second line, on the other hand, is intended to benefit others, without the explicit demand of an immediate and proportional return. This unethical behaviour is motivated on grounds of mutual trust and consequentialist considerations of the positive effect on the other. In terms of the bottom line, cell 7 stands out as a particular category. Unethical behaviour here includes explicit disobedience of rules, laws and orders: anarchy. Cells 8 and 9 both refer to an excessive use of the deontological way of ethical reasoning.

\section{PROPOSING A THEORY}

With the elements of the conceptual framework defined and operationalized, we can now propose the actual theory, starting with the basic proposition,

\section{TABLE 2 Nine types of unethical behaviour}

\begin{tabular}{|c|c|c|c|}
\hline $\begin{array}{l}\text { Locus of analysis/ } \\
\text { ethical criterion }\end{array}$ & Individual & Local & Cosmopolitan \\
\hline Egoism & $\begin{array}{l}\text { Selfishness (corruption } \\
\text { sensu stricto) }\end{array}$ & $\begin{array}{l}\text { Organization-fetishism } \\
\qquad(2)\end{array}$ & $\begin{array}{l}\text { Efficiency-fetishism } \\
\text { (3) }\end{array}$ \\
\hline Benevolence & Nepotism & Team-fetishism & $\begin{array}{l}\text { Preferential treatment } \\
\text { of stakeholders }\end{array}$ \\
\hline Principle & Anarchy & Rule-fetishism & $\begin{array}{l}\text { Law-, and principle- } \\
\text { fetishism }\end{array}$ \\
\hline
\end{tabular}


an empirically falsifiable claim. The relative intensity of the interaction types, is proportional:

- to the relative intensity of the respectively related ethical standards in ethical decision making; and

- to the relative frequency of occurrence of the respectively related types of unethical behaviour.

In other words, when a particular interaction type is dominant, then the concomitant ethical standard will be dominant in ethical decision making and thus the chance will increase that the standard will be applied excessively (that is, unethical behaviour, see above). This proposition is based on two fundamental claims, each of which are central to 'grid-group theory', which also provided the typology for organizational processes (see above). First, the proposition is based on grid-group theory's basic claim that in any organizational setting there is always a mutually supportive relationship between the structure of the organization and the dominant values and beliefs (Thompson et al. 1990; Hood 1998). A certain type of structure (or set of social relations) will tend to go together with a certain set of values and beliefs (or cultural bias). Grid-group theorists call this the compatibility condition' (Thompson et al. 1990, p. 2). Only a certain combination of types of values and social relations provides a reasonably stable and 'viable' organization. With 'organizational processes' being similar to grid-group theory's 'social relations', and 'ethical decision making standard' and 'type of unethical behaviour' being equivalent to 'cultural bias', it is clear how grid-group theory provides the theoretical support for the proposition specified above. Second, grid-group theory also provided support for the claim that, when an interaction pattern is dominant, the chance of the unethical behaviour associated with this interaction pattern occurring increases. Grid-group theorists argue that the different interaction patterns depend upon each other to make up for their deficiencies (Thompson et al. 1990). The theory presented here, defines 'deficient consequence of an interaction type' as the unethical behaviour that is hypothesized to be causally associated with it. According to grid-group theory, this can only be dealt with by reducing the dominance of that interaction pattern by applying other patterns and thus ensuring more balance between the interaction patterns. Organizations that are able to establish such a volatile 'coalition' between the four interaction types (including 'fatalism') have been called 'clumsy institutions' (Thompson 2002). Hence, the prescriptive bias behind both grid-group theory and the presented theory is that unethical behaviour can be avoided by ensuring that the different interaction types are sufficiently represented so that the critical voice of each type will be heard and no interaction type will dominate.

Table 3 specifies the associations between the respective types. The propositions (' $\left.\mathrm{P}^{\prime}\right)$ can be summarized as follows. Each of the three interaction types is associated with one of the three ethical criteria (individualism 
with egoism, egalitarianism with benevolence, and hierarchy with principle) and hence with the respective ethical standards and types of unethical behaviour. There is one exception to this general rule: the personal morality standard is defined by the principle criterion, but is associated in table 3 with the egalitarian interaction pattern (and not the hierarchist interaction pattern).

\section{TOWARDS A THEORY ABOUT THE CAUSAL RELATIONSHIP BETWEEN NPM AND PUBLIC SERVANTS' ETHICS}

This section translates the propositions that underlie the positions in the NPM-ethics debate into the language of the conceptual framework that was presented in section 1. It will demonstrate that each of the propositions formulated in the NPM-ethics debate is paralleled by a proposition set out in table 3 . Thus, the propositions that seemed rival are actually complementary and, once they are all put into the same 'language', they amount to one coherent theory. Hence, the aim of this paragraph is not to collect empirical data, but to bring the diverse empirical claims made in the NPM-ethics literature together in one theory. This then provides the conceptual clarity and theoretical framework that are necessary for systematic empirical testing of those propositions.

First, the three propositions (see arrows in table 3) about the causal relationship between 'organizational processes' and 'ethical decision making' will be discussed. Each of these will turn out to have strong advocates in the NPM-ethics literature. Then, the relationship between organizational processes and 'unethical behaviour' (through ethical decision making) will be addressed. Again, the NPM-ethics literature provides strong underpinnings for each of these propositions, but now presented by the opponents of the respective interaction types.

TABLE 3 The theory's propositions

Organizational
processes




\section{The causal relationship between organizational processes and ethical decision making}

Proposition 1: there is a reciprocal causal relationship between individualism and the following standards: self-interest (table 1, cell 1), organizational interest (table 1, cell 2), and efficiency (table 1, cell 3).

The strongest support for the claim that the individualist interaction pattern leads to the ('ethically desirable') standards of self-interest (table 1, cell 1), organizational interest (table 1, cell 2) and efficiency (table 1, cell 3) can, of course, be found in NPM. This administrative philosophy can be divided into two subsets of administrative doctrines, congruent with the two phases in the reform movement (at least in the UK and the US) that have been observed by Pollitt (1993) and others. In a first phase the NPM-reforms were focused on neo-Taylorian changes aimed at cost-cutting and the introduction of the individualist interaction pattern in government. One of the most important intellectual sources of this administrative philosophy is the public choice school, which borrowed the core assumption from economic theory that human beings (including public servants) are self-interested utility maximizers. The challenge then is to organize the organizational processes in such a way that this self-interested behaviour still leads to a well-performing government that 'works better and costs less' (Gore 1996). The only interaction type that is really capable of doing this is, according to the NPMadherents, the individualist way. The introduction of a competitive pay for performance scheme, for example, will lead to the domination of the selfinterest standard (table 1, cell 1) in ethical decision making, which, in turn, will have a positive effect on government performance; at least on the condition that the public servants under the scheme compete on the basis of 'the right' performance indicators. When a public sector organization competes with other (private or public sector) organizations, this will lead to the efficiency standard (table 1, cell 3) dominating ethical decision making, or in some cases the organizational interest standard (table 1, cell 2).

The second phase in the reform movement has been described as 'the coming of quality' (Pollitt 1993) or the 'soft path' (Lynn, cited in deLeon 1998 , p. 540). It marks a move away from the 'bureaucrat-bashing' and costcutting focus of the early NPM-years towards an emphasis on quality and customer service orientation. The empirical claims of the authors writing in this 'quality' strand of the NPM literature are somewhat ambiguous. Their rhetoric usually contains some references to direct democracy or citizen involvement (that is, egalitarianism), but the actual proposals (and their actual implementation) mostly contain individualist elements: improving quality of services in order to increase profits and as long as the organization benefits from it. In the language of the framework, the quality movement proponents claim that the introduction of quality-oriented measures will lead to a domination of both the stakeholder orientation standard (table 1, cell 6) and the organizational interest (table 1, cell 2) and efficiency (table 1, cell 3) 
standards, but in practice, they concentrate on the latter two (for the British case, see for example Bellamy and Greenaway (1995)).

Proposition 2: there is a reciprocal causal relationship between egalitarianism and the following standards: (a) friendship (cell 4); team interest (table 1, cell 5) and stakeholder orientation (table 1, cell 6); and (b) personal morality (table 1, cell 7).

Not surprisingly, the most forceful support for the proposition that the egalitarian interaction pattern leads to the types of ethical decision making listed in this second proposition, is provided by doctrines of the NPS administrative philosophy. Two other approaches also provide some support for specific claims, but only partially so since they would always argue to complement the egalitarian measures with their own preferred interaction pattern. I discuss each in turn.

First, as mentioned above, the NPM doctrines about service and quality management contain some egalitarian elements and these are assumed to lead public servants to use the stakeholder orientation standard (table 1, cell 6) in their ethical decision making. The potential unethical behaviour associated with this standard (preferential treatment of stakeholders) should, in the NPM-logic, be avoided by combining this with a competitive interaction pattern that guarantees that the efficiency standard will counterbalance the stakeholder orientation. Similarly, within the organization, quality management doctrines also sometimes assume the positive effects of 'team-work' and other egalitarian interaction patterns (Osborne and Gaebler 1992; Nufrio 2001, pp. 14-15), but again counterbalance these with competition mechanisms that focus on the individual (not always making explicit the tension between both interaction types).

Second, the 'integrity' approach of the Ethics Management adherents also contains a strong element of egalitarianism. The hypothesis is that more egalitarianism will lead people to reason on the basis of the personal morality standard (table 1, cell 7), which is considered to be a desirable complement for the ethical standards that follow from NPM-type individualist interaction patterns. However, according to the 'Ethics Management' authors, this integrity-style ethics management by itself will not do. There is still need for a basic set of compliance-based arrangements or, in the words of Uhr (1999), the 'values set' of integrity institutions needs to be balanced with the 'verification set' of institutions. Hence it is better to conceive of the compliance and integrity approaches to ethics management as two ideal types at the ends of a continuum, rather than as mutually exclusive categories (Gilman 1999). The Ethics Management advocates prefer a position that is closer to the integrity approach but still contains a number of significant compliance elements.

While the others assume that egalitarianism (when it has beneficial effects also) always needs to be balanced by one of the other interaction types, the NPS advocates seem to assume that egalitarianism is diverse enough to 
provide sufficient variation in itself. They make, for example, a distinction between egalitarianism within a public sector organization and egalitarianism between organizational members and outsiders. As for the latter, NPSproponents argue that the processes of a public sector organization need to be designed in such a way that the public servants can 'focus on building relationships of trust and collaboration with and among citizens' (Denhardt and Denhardt 2000). The NPS advocates then hypothesize that this egalitarianism between organizational members and outsiders will lead to the stakeholder orientation standard (table 1, cell 6): public servants will consider the consequences of their actions for the stakeholders they are confronted with, that is, they will 'attend to (...) citizen interests' (Denhardt and Denhardt 2000, p. 554). This is not sufficient, however, since this might lead to partiality and preferential treatment of those stakeholders (table 2, cell 6). Therefore, this should be complemented by a considerable amount of egalitarianism within the organisation, for example, in the form of shared leadership, collaboration or empowerment. These latter measures are hypothesized to have two effects on the ethics of public servants. First, and most importantly, they will lead to the dominance of the personal morality standard (table 1, cell 7), because 'leadership exercised by working through and with people transforms the participants and shifts their focus to higher level values' (ibid., p. 556). When this standard dominates, public servants will follow their own principles and the continuing dialogue ad exchange of views both within and outside the organizations will then ensure that these 'personal principles' will in fact be those principles that are desired by all parties. This is consistent with the observation of many students of moral development that the level of moral reasoning increases through an open and constructive exchange of views (for example, the 'Just Community approach of Kohlberg' (1984), see Vidaver-Cohen (1998, pp. 1212-13)). In any case, this personal morality standard will help to ensure that public servants look beyond the immediate interests of the stakeholders they are dealing with, and will as such reduce the potential dangers of a too strong application of the stakeholder orientation standard. A second implication of egalitarianism within the organization will be mutual respect among members of the organization, that is, the friendship (table 1, cell 4) and team interest (table 1, cell 5) ethical standards.

Proposition 3: There is a reciprocal causal relationship between hierarchy and the following standards: organizational rules (table 1, cell 8) and laws and public interest (table 1, cell 9).

Those arguing from the TPA philosophy essentially contend that their hierarchist doctrines will lead to the organizational rules (table 1, cell 8) and laws and public interest (table 1, cell 9) standards and evaluate this positively. As for hierarchy within the organization, Frederickson for example argues that 'in their enthusiasm for cutting red tape (...), managers should remember why some of that red tape got there in the first place', and he mentions 'due process and fairness' and 'compassion and protection' as 'just 
two reasons' (Frederickson 1999, pp. 267-8). Confronted with de-regulation, privatization, contracting out and other typical NPM-reforms, Frederickson predicts that 'in 2010 the ancient saying "today's problems are yesterday's solutions" will have come to pass' and hence a 'step-by-step process of re-regulation' with 'as primary impetus (...) the issue of fairness' will be inevitable (ibid., pp. 275-6). Those TPA-advocates that write from a legalistic perspective take the same position and particularly emphasize the typically hierarchist argument that 'private management' is fundamentally different and distinct from 'government management' as the latter has its basis in and is constrained by public law (see for example, Moe and Gilmour 1995, p. 138). The TPA-proponents also argue for a hierarchist interaction pattern with citizens, contrasting this with the customer service orientation of NPM. They point out that the private interests of clients do not necessarily coincide with the public interest and that public servants have a 'public duty' (Chapman and O'Toole 1995) that goes far beyond the immediate stakes of the stakeholder they are dealing with.

\section{The causal relationship between organisational processes and unethical behaviour}

This subsection lists the propositions in the NPM-ethics literature that parallel the three propositions in table 3 about the relationship between interaction types and types of unethical behaviour (as mediated by types of ethical decision making). In the previous subsection it was demonstrated how the respective advocates of each of the four positions in the NPM-ethics debate emphasized how their own preferred interaction pattern causes ethical decision making. This subparagraph will demonstrate how they emphasize that the interaction patterns they dislike lead to unethical behaviour. Since the proposed conceptual framework includes both unethical behaviour and ethical decision making, all these claims can be integrated into the general theory developed above and the 'rival doctrines' will turn out to be surprisingly complementary.

Proposition 4: there is a reciprocal causal relationship between individualism and the following unethical behaviour types: organization fetishism (table 2, cell 2), and efficiency-fetishism (table 2, cell 3).

Of course, most NPM-advocates are aware that individualism sometimes causes unethical behaviour. They have two standard explanations for this. First, they argue, individualism can lead to unethical behaviour when the competition mechanisms are not designed in an appropriate way. Performance management systems, for example, need to be designed in such a way that the indicators are the 'right' ones and that the self-interested behaviour is guided in such a way that it also advances the government's goals. Second, much of the unethical behaviour that is assumed to follow from introducing competition mechanisms is, according to the NPM-adherents, in fact caused by the lack of actual competition. For example, an agency 
might be put at arm's length and forced to compete with private sector companies for the product it delivers to the overseeing ministry. However, when it turns out that no private companies are interested in providing the product, the agency will have a monopoly position. The agency might then underperform and provide low quality products to its overseeing ministry. This self-interested, unethical behaviour is, according to the NPM-proponents, not a consequence of the introduction of individualism but of the actual lack of individualism. The advocates of the other three approaches do not accept these two explanations on the basis of two reasons, focusing on organizational processes and unethical behaviour respectively.

The first reason concentrates on the organizational processes and is most strongly argued for by the Ethics Management advocates. Essentially, their argument is that there are some inherent problems with applying pure individualism in the public sector, which cannot be solved by simply improving or enhancing competition. They develop this argument for the two 'strands' of NPM. First, as for the Neo-Taylorian strand or 'Taylorism in disguise' (Theobald 1997, p. 497), warnings abound about the inherent problems with performance management in the public sector. Ott et al. (2001), for example, observe that traditional hierarchical forms of accountability have been seriously diminished, on the assumption that new forms of accountability, and particularly performance measurement, are a better alternative. However, since performance measurement has not been able (yet) to provide the information needed in important areas of government activity, the net result of this operation has been a diminished degree of accountability. DeLeon (1998) is one among many who point out that these problems are, to an extent, inherent, since 'accountability for results is possible only where goals are clear' (p. 546). A second target of this type of critique have been the quality management measures of NPM, and particularly the use of individualisttype service management techniques in the public sector and the 'customer service orientation' underlying it. Brans (1997), for example, points out that the customer concept emphasizes the 'exit' option as a tool to express discontent, rather than 'voice'. 'It obscures, however, the fact that citizens without resources - the willingness to pay is an important assumption of the market metaphor - may be left without any voice at all' (p. 406). In the language of the conceptual framework, this implies that individualism fosters an excessive use of the organizational interest (table 2, cell 2) and efficiency (table 2, cell 3) standards, to the detriment of other more traditional public sector values, such as equity. In sum, all these examples demonstrate that competition in the public sector often turns out to work differently from the way it was initially intended, fostering the typical types of unethical behaviour associated with individualism. Hence, Ethics Management proponents argue, the introduction of individualism should be well-considered and should always be complemented with measures of ethics management that are a combination of hierarchist ('compliance') and egalitarian ('integrity') interaction patterns. 
The second reason is partly supported by the 'Ethics Management' adherents but most strongly formulated by those arguing from TPA and NPS. This argument focuses on the 'unethical behaviour', rather than on the organizational processes and their potential deficiencies. The contention is that increasing competition also increases the chance that the unethical behaviour of cell 1,2 and 3 will occur, not because of a badly designed competition system (the argument of the NPM-proponents) or because competition is impossible (Ethics Management proponents), but because competition mechanisms change the values of public servants. Individualist organizational processes almost reverse the traditional hierarchy of values ('first legality, then equity, effectiveness and efficiency and lastly economy' (Bouckaert 1995, p. 170)) to one in which the latter three ('the three E's') come first. Thus the chance increases that the unethical behaviour associated with individualism will occur. The TPA-advocates argue this most strongly, referring to the 'demise of public duty' (Chapman and O'Toole 1995) as a consequence of increased competition. Authors from the legal strand within TPA then particularly emphasize that NPM's individualist emphasis on increased executive discretion sits uncomfortable with the, from a legal point of view crucial, problem of 'control of administrative discretion to assure compliance with legal standards to protect the individual from arbitrary action or tyranny' (Carroll 1995, p. 308). Yet, also the NPS-proponents emphasize that 'the public interest is the aim, not the by-product' (Denhardt and Denhardt 2000, p. 554). They also point at the value of the political debate in itself, since it raises awareness of other stakeholder' values and interests and might even transform preferences, rather than simply aggregate them, as the individualists propose (Bellamy and Greenaway 1995, pp. 490-1).

Proposition 5: there is a reciprocal causal relationship between egalitarianism and the following unethical behaviour types: team-fetishism (table 2, cell 5) and preferential treatment of stakeholders (table 2, cell 6); and (b) anarchy (table 2, cell 7).

While ethical criticism on the individualist interaction pattern abounds, the concerns about unethical behaviour that might be fostered by the egalitarian interaction pattern have been, up to now, rather modest in the NPM-ethics debate. The NPM-critics have concentrated on the individualist aspects of NPM, which were indeed the core of its rhetoric. Moreover, the recent revival of the NPS is probably too young and not enough adopted in practice to bring about the sort of critical wave fostered by the individualist NPM-reforms. On the basis of the theory the concerns can be expected to go in two directions.

The first concerns focus on the proposition that the egalitarian interaction pattern causes the three types of unethical behaviour associated with the benevolence criterion. Hood (1998, p. 41) notes, for example, that egalitarianism within an organization might 'degenerate into "coexistence", with a 
tendency for each of the colleagues in the group to avoid asking awkward questions about the behaviour of colleagues'. This is what the proposed conceptual framework describes as 'team-fetishism' (table 2, cell 5). As for egalitarianism between public servants and outsiders, those quality management measures that imply direct citizen- or employee-involvement in decision making, can also be criticized, particularly from a TPA-perspective. The argument then is that that kind of egalitarianism (as far as it is genuine and not individualism in disguise, see above) can foster an excessive application of the stakeholder orientation standard (table 2, cell 6) and thus preferential treatment of citizens (table 2, cell 6).

A second concern is also most strongly maintained by TPA-arguments. It parallels the proposition that egalitarianism can cause an excessive application of the personal morality standard (table 2, cell 7), eventually leading to anarchy or, in a more organized form, a Beamtenherrschaft. This obviously echoes the concerns of Weber, Finer and many others about the potential dangers for democracy of too much discretion for public servants. Dunleavy and Hood (1994, p. 14) argued that one consequence of NPM-type reforms might be the creation of a 'headless chicken model' (see also Rhodes 2000), typified by a 'no-one in charge public management'. They focused on the interorganizational (macro-) level, but it is obvious that this is also a potential danger at the meso- and micro-levels.

Proposition 6: there is a reciprocal causal relationship between hierarchy and the following unethical behaviour types: rule-fetishism (table 2, cell 8 ) and law- and principle-fetishism (table 2, cell 9).

Public administration and organizational theory have a long tradition of critique on the hierarchist interaction pattern and its excesses or the 'bureaupathologies' (Van Wart and Denhardt 2001, p. 237). To cite just one classic example, Merton describes how in a bureaucracy '[a]dherence to the rules originally conceived as means, becomes transformed into an end-initself (...). Formalism, even ritualism, ensues with an unchallenged insistence upon punctilious adherence to formalized procedures' (Merton 1968, p. 253; cited in Denhardt 1994, p. 171). In the NPM-ethics debate as well, fierce criticism has been expressed on the hierarchist interaction pattern, particularly from the NPM and the NPS administrative philosophies. As for the former, the whole NPM-rhetoric can be seen as an assault on the traditional hierarchist structure as being overpriced, underperforming and impeding the implementation of profitable and worthwhile doctrines such as 'hands-on' entrepreneurial management or accountability for results. 'Homiletic' (Lynn 1996) works like Osborne and Gaebler (1992)'s classic Reinventing Government contain numerous examples of the proposition that the hierarchist interaction pattern leads to rule- (table 2, cell 8) and law- (table 2, cell 9) fetishism. NPS-advocates essentially make the same empirical claim, but on different normative grounds. They are mainly concerned about the dehumanizing (Adams and Balfour 1998) and depersonalizing aspects of 
hierarchy. They criticize the hierarchist structure for allowing 'an individual to be a good administrator while committing acts of evil' (p. 170) as well as for its tendency to separate the bureaucrat from the morally conscious human being. NPS-advocates emphasize that people should be conscious that 'the notion of individual ethical responsibility is not absolved by hierarchical systems' (Gawthrop 1998, p. 22).

Interestingly, most of the alternatives that are provided by the NPMauthors also contain a considerable degree of hierarchy. Measures for quality improvement, for example, not only include strong individualist and some egalitarian elements, but also aim at improving and rationalizing the processes in the organization and at introducing quality indicators. All this includes a considerable degree of formalization, leading some to suggest that NPM could be seen as a further step in the bureaucratization, rather than a move away from it (Hood 1994, p. 138; Theobald 1997, p. 497). Similarly, NPM-type reforms to give managers increased discretion, while enhancing their 'ex post' accountability, can also include many hierarchist elements. Commenting upon practices in New Zealand, Gregory and Hicks (1999) observe that through the new contractualist regime, in fact 'one type of rules-based approach was replaced by another: impersonal bureaucratic rules were increasingly replaced by personalized legal contracts' (p. 12). The NPM-advocates seem to assume that, although these and other proposals include a significant degree of hierarchy, they will not lead to the kind of unethical behaviour that they hypothesize to be caused by TPA's hierarchist practices.

\section{CONCLUSION}

The main goal of the paper was to bring conceptual clarity into the array of diverse and non-cumulative claims about the causal relationship between NPM-reforms and the ethics of public servants. This was done on the basis of a conceptual framework. The basic argument of the paper then was that it is possible to translate the empirical claims made by the advocates in the NPM-ethics debate into the language of that framework and thus develop a general and falsifiable theory about public servants' ethics. It turned out that the empirical claims of the four 'rival' positions in the debate were not rival, but complementary. This somewhat paradoxical observation can be understood by addressing the two types of biases that underlie each of the four positions in the debate. First, as mentioned above, they are all four biased in their perception. They tend to concentrate mainly on the beneficial effects (that is, ethical decision making) of their preferred interaction type, while developing something like a blind spot for the potential deficiencies (that is, unethical behaviour). However, since the other approaches then point at these deficiencies while focusing on the beneficial effects of their own preferred interaction type, these claims aggregate to one coherent theory. Second, when proponents of a particular approach do consider the potential unethical behaviour associated with their preferred interaction pattern, they 
have a normative-ethical bias in the sense that they tend to evaluate the unethical behaviour associated with the other interaction patterns much more negatively.

At the outset, it was observed that considerate public administrationists would be more confused than helped by the diverse empirical claims in the NPM-ethics literature. This article aimed to provide them with two preliminary answers, each of which requiring further development. First, the article proposed an initial step towards a theory on the basis of which it should be possible to predict the ethical decision making standards and types of unethical behaviour associated with a particular interaction pattern. Although each of the propositions is paralleled by claims in the NPM-ethics literature, each of which usually supported by examples, the real test will be in systematic empirical research. Survey research would be appropriate to test the hypotheses, while qualitative case oriented research (Yin 1994) would help to modify and expand the theory. Two basic case study designs seem to be particularly appropriate for this purpose: a comparison of one case (that is, organization) at different points in time (for example, comparing 'before' and 'after' NPM-type changes) or a comparison between different organizations (differing in their interaction types). The theory will also need theoretical expansion. The discussion explicitly excluded questions about the environment of the organization and its impact on organizational processes and, ultimately, on the ethics of the organizational members, because this aspect has been theorized more systematically (see for example Romzek and Dubnick 1987; deLeon 1998; Dubnick 1998) than the impact of intra-organizational interaction patterns on ethics. However, the impact of the environment is obvious and needs to be included in an expanded version of the theory. It can build on previous theoretical work of Romzek and Dubnick (1987), deLeon (1998), grid-group theorists like Coyle (1997) and others.

Second, the article provided the practical advice that the dominance of a single interaction pattern does increase the chance of the associated type of unethical behaviour occurring. Hence, a public administrator should aim to combine the three interaction types and hence combine doctrines from the different approaches (discussed in the introduction), rather than singlemindedly committing to one of them. In itself, there is nothing spectacular about this advice to balance the different approaches. Indeed, the fourth approach discussed in the introduction, Ethics Management, gives similar advice. Even authors who are less explicit about combining approaches, do consider doctrines of other approaches. Frederickson, for example, often expresses a strong preference for the hierarchist interaction pattern (see for example Frederickson 1999), but he also is sympathetic to NPS-type egalitarian administrative doctrines (e.g. 1997). On the other side of the spectrum, Borins (1999) clearly defends many individualist elements of NPM (for example, competition, public entrepreneurship, 'encouraging heroism' (p. 286)), but complements this with egalitarian elements and advice to 'inculcate values to guide the public sector's would-be innovators' (p. 385). 
Although it has these parallels in the NPM-ethics literature, the gridgroup theory advice to balance the three interaction types nevertheless does have two additional advantages. First, by using a theoretically sound and empirically useful typology, it does make the debate more subtle and explicit, while still keeping it manageable. For example, its threefold typology is broader and more developed than the 'compliance-integrity' continuum used by the Ethics Management proponents. Second, the link with grid-group theory will also allow the NPM-ethics literature to build on the literature about 'clumsy institutions,' which further grounds and develops the vague advice to balance the different interaction patterns (Thompson 1997, 2002; Verweij forthcoming; 6 forthcoming). This is an emerging literature now evolving in promising directions.

\section{ACKNOWLEDGEMENT}

Earlier versions of the paper were presented at the ECPR joint workshops in Grenoble, France (2001, workshop 16: scandal and the contestation of governance in Europe), at the national conference of the American Society for Public Administration in Phoenix, Arizona, US (2002) and at the conference of the International Public Management Network in Siena, Italy (2002). The author wishes to thank the participants to these events for their comments and suggestions. The author is also grateful to Michael Barzelay, Nathalie Behnke, Geert Bouckaert, Marleen Brans, Annie Hondeghem, Les Metcalfe, Ninke Mussche, Ed Page, B. Guy Peters, Perri 6 and 3 anonymous referees for their very useful comments and suggestions.

\section{REFERENCES}

6, P. forthcoming. The Governance of Friends: Public Policy and Personal Social Networks. Cambridge: Cambridge University Press.

Adams, G.B. and D.L. Balfour. 1998. Unmasking Administrative Evil. Thousand Oaks, CA: Sage.

Agarwal, J. and D.C. Malloy. 1999. 'Ethical Work Climate Dimensions in a Not-for-profit Organization: an Empirical study', Journal of Business Ethics, 20, 1-14.

Akaah, I.P. 1992. 'Social Inclusion as a Marketing Ethics Correlate', Journal of Business Ethics, 11, 8, 599-608.

Barzelay, M. 2001. The New Public Management. Improving Research and Policy Dialogue. Los Angeles, CA: University of California Press.

Bellamy, R. and J. Greenaway. 1995. 'The New Right Conception of Citizenship and the Citizen's Charter', Government and Opposition, 30, 4, 469-91.

Borins, S. 1999. 'Innovating with Integrity: Evidence from the Ford Foundation-Kennedy School of Government Awards', Public Integrity, 1, 4, 375-87.

Bouckaert, G. 1995. 'Concluding Reflections', in C. Pollitt and G. Bouckaert (eds), Quality Improvement in European Public Services. Concepts, Cases and Commentary. London: Sage, pp. 162-73.

Bouckaert, G. and C. Pollitt. 2000. Public Management Reform. A Comparative Analysis. Oxford: Oxford University Press.

Brans, M. 1997. 'Challenges to the Practice and Theory of Public Administration in Europe', Journal of Theoretical Politics, 9, 3, 389-415.

Carroll, J.D. 1995. 'The Rhetoric of Reform and Political Reality in the National Performance Review', Public Administration Review, 55, 3, 302-12.

Chapman, R.A. 1994. 'Change in the Civil Service', Public Administration, 72, 599-610. 
Chapman, R.A. 1998. 'Problems of Ethics in Public Sector Management', Public Money and Management 1, 9-13.

Chapman, R.A. and B.J. O'Toole. 1995. 'The Role of the Civil Service: a Traditional View in a Period of Change', Public Policy and Administration, 10, 2, 3-20.

Cohen, S. and W. Eimicke. 1999. 'Is Public Entrepreneurship Ethical?', Public Integrity, 1, 1, 54-74.

Cooper, T.L. 1982. The Responsible Administrator: an Approach to Ethics for the Administrative Role, 1st edn. Port Washington, NY: Kennikat.

Cooper, P.J. 2000. Public Law and Public Administration, 3rd edn. Itasca, IL: F.E. Peacock.

Coyle, D.J. 1997. 'A Cultural Theory of Organizations', in R. Ellis and M. Thompson (eds), Culture matters. Essays in honor of Aaron Wildavsky. Boulder, CO: Westview Press, pp. 59-78.

deLeon, L. 1998. 'Accountability in a "Reinvented" Government', Public Administration, 76, 539-58.

Denhardt, K.G. 1994. 'Organizational Structure as a Context for Administrative Ethics', in T.L. Cooper (ed.), Handbook of Administrative Ethics. New York: Marcel Dekker, pp. 169-82.

Denhardt, R.B. and J.V. Denhardt. 2000. 'The New Public Service: Serving Rather than Steering', Public Administration Review, 60, 6, 5549-59.

Douglas, M. (ed.). 1978. 'Cultural Bias', In the Active Voice. London: Routledge.

Dubnick, M.J. 1998. 'Clarifying Accountability: an Ethical Theory Framework', in C. Sampford and N. Preston (eds), in Public Sector Ethics. Finding and Implementing Values. London: Routledge, pp. 68-81.

Dunleavy, P. and C. Hood. 1994. 'From Old Public Administration to New Public Management', Public Money and Management, 14, 3, 9-16.

Fox, C.J. 2001. 'The Use of Philosophy in Administrative Ethics', in T.L. Cooper (ed.), 2nd edn, Handbook of Administrative Ethics. New York: Marcel Dekker, pp. 105-30.

Fox, C.J. and H.T. Miller. 1996. Postmodern Public Administration. Towards Discourse. Thousand Oaks, CA: Sage.

Frederickson, H.G. (ed.). 1993. Ethics and Public Administration. New York: M.E. Sharpe.

Frederickson, H.G. 1997. The Spirit of Public Administration. San Francisco, CA: Jossey-Bass.

Frederickson, H.G. 1999. 'Public Ethics and the New Managerialism', Public Integrity, 1, 3, 265-78.

Fritzsche, D.J. and H. Becker. 1984. 'Linking Management Behavior to Ethical Philosophy. An Empirical Investigation', Academy of Management Journal, 27, 1, 166-75.

Gawthrop, L.C. 1998. Public Service and Democracy. New York: Chatham House.

Gilman, S.C. 1999. 'Public Sector Ethics and Government Reinvention: Realigning Systems to meet Organizational Change', Public Integrity, 1, 2, 175-92.

Gore, Al. 1996. 'A Report to President Bill Clinton: the best kept secrets in government', National Performance Review, Washington DC: Vice President Al Gore.

Greenaway, J. 1995. 'Having the bun and the halfpenny: can old public service ethics survive in the New Whitehall?', Public Administration, 73, 357-74.

Gregory, R. and C. Hicks. 1999. 'Promoting Public Service Integrity: a case for Responsible Accountability', Australian Journal of Public Administration, 58, 4, 3-15.

Hirschman, A.O. 1970. Exit, Voice and Loyalty: Responses to Decline in Firms, Organizations and States. Cambridge, MA: Harvard University Press.

Hondeghem, A. (ed.). 1998. Ethics and Accountability in a context of Governance and New Public Management. Amsterdam: IOS Press.

Hood, C. 1991. 'A Public Management for all seasons?', Public Administration, 69, 1, 3-19.

Hood, C. 1994. Explaining Economic Policy Reversals. Buckingham: Open University Press.

Hood, C. 1998. The Art of the state. Culture, Rhetoric, and Public Management. Oxford: The Clarendon Press.

Hood, C. and M. Jackson. 1991. Administrative Argument. Aldershot: Dartmouth.

Hunt, S.D. and A.Z. Vazquez-Parraga. 1993. ‘Organizational consequences, Marketing ethics and Saleforce satisfaction', Journal of Marketing Research, 12, 78-90.

Kaptein, M. 1998. Ethics Management. Auditing and developing the ethical content of organizations. Dordrecht: Kluwer.

Klitgaart, R. (ed.). 1988. Controlling Corruption. Los Angeles, CA: University of California Press.

Kohlberg, L. 1984. The Psychology of Moral Development: Moral Stages and the Life Cycle. Vol. 2. San Francisco, CA: Harper and Row.

Lynn, L.E. Jr. 1996. Public Management as Art, Science, and Profession. Chatham, NJ: Chatham House. 
McNeil, M. and A. Peachment. 1996. 'Ethics and the Public Sector Manager: a Comparative Treatment of the Western Australian Public Sector', The Journal of Contemporary Issues in Business and Government, 2, 2, 5-15. Menzel, D.C. 2000. 'The Morally Mute Manager: Fact or Fiction?' , Public Personnel Management, 28, 4, 515-27. Merton, R.K. 1968. Social Theory and Social Structure. New York: The Free Press.

Moe, R.C. and R.S. Gilmour. 1995. 'Rediscovering Principles of Public Administration: the Neglected Foundation of Public Law', Public Administration Review, 55, 2, 135-46.

Newland, C.A. 1994. 'A Field of Strangers in search of a discipline: Separatism of Public Management Research from Public Administration', Public Administration Review, 54, 5, 486-88.

Nufrio, P.M. 2001. Changing Organisational Culture. A Study of the National Government. Lanham, MD: University Press of America.

OECD. 1996. Ethics in the Public Service. Current Issues and Practices. Paris: OECD.

OECD. 2000. Trust in Government. Ethics measures in OECD countries. Paris: OECD.

Osborne, D. and T. Gaebler. 1992. Reinventing Government. How the Entrepreneurial Spirit Is transforming the Public Sector. New York: Basic Books.

Ott, J.S., P. Boonyarak, and L.A. Dicke. 2001. 'Public Sector Reform, and Moral and Ethical Accountability', Public Integrity, 3, 277-89.

Ouchi, W.G. 1980. 'Markets, Bureaucracies, and Clans', Administrative Science Quarterly, 25, 121-41.

Petrick, J.A. and J.F. Quinn. 1997. Management Ethics. Integrity at Work. London: Sage.

Pollitt, C. 1993. Managerialism and the Public Services, 2nd edn, Oxford: Blackwell.

Rhodes, R.A.W. 2000. 'Different Roads to Unfamiliar Places: UK Experience in Comparative Perspective', Australian Journal of Public Administration, 57, 4, 19-31.

Rohr, J.A. 1978. Ethics for Bureaucrats: an Essay on Law and Values. New York: Marcel Dekker.

Rohr, J.A. 2002. Civil Servants and their Constitutions. Lawrence, KS: University Press of Kansas.

Romzek, B.S. and M.J. Dubnick. 1987. 'Accountability in the Public Sector: Lessons from the Challenger Tragedy', Public Administration Review, 47, 3, 227-38.

Rosenbloom, D.H., J.D. Carroll, and J.D. Carroll. 2000. Constitutional Competence for Public Managers, $2^{\text {nd }}$ edn, Itasca, IL: F.E. Peacock.

Sims, R.L. and T.L. Keon. 1999. 'Determinants of Ethical Decision Making: the Relationship of the Perceived Organizational Environment', Journal of Business Ethics, 19, 393-401.

Skidmore, M.J. 1995. 'Ethics and Public Service', Annals of the American Academy of Political and Social Science, 537, 25-36.

Stewart, D.W. and N.A. Sprinthall. 1993. 'The Impact of Demographic, Professional, and Organizational Variables and Domain on the Moral Reasoning of Public Administrators', in H.G. Frederickson (ed.), in Ethics and Public Administration. New York: M. E. Sharpe, pp. 205-19.

Stewart, D.W., N.W. Sprinthall, and D.M. Shafer. 2001. 'Moral Development in Public Administration', in T.L Cooper (ed.) 2nd edn, Handbook of Administrative Ethics. New York: Marcel Dekker, pp. 457-80.

Theobald, R. 1997. 'Enhancing Public Service Ethics', Administration and Society, 29, 4, 490-505.

Thompson, M. 1997. 'Rewriting the Precepts of Policy Analysis', in R.J. Ellis and M. Thompson (eds), Culture Matters. Essays in Honor of Aaron Wildavsky. Boulder, CO: Westview Press, pp. 203-16.

Thompson, M. 2002. The Case for Clumsiness. Unpublished paper.

Thompson, M., R. Ellis, and A. Wildavsky. 1990. Cultural Theory. Boulder, CO: Westview Press.

Trevino, L.K. 1986. 'Ethical Decision Making in Organizations: a Person-situation Interactionist Model', Academy of Management Review, 11, 3, 601-17.

Uhr, J. 1999. 'Institutions of Integrity. Balancing Values and Verification in Democratic Government', Public Integrity, 1, 1, 94-106.

United States Senate. 1991. 'Measuring Program Performance: Getting the most Bang for the Buck', in Hearing before the Committee on Governmental Affairs, U.S. Senate, 102nd Congress, First Session, May 23, 1991. Washington DC: US Government Printing Office.

van Gunsteren, H.R. 1991. 'The Ethical Context of Bureaucracy and Performance Analysis', in F.-X. Kaufman (ed.), The Public Sector. Challenge for Coordination and Learning. Berlin: Walter de Gruyter, pp. 309-23.

Van Reeth, Wouter. 2002. 'The Bearable Lightness of Budgeting: the Uneven Implementation of Performance Oriented Budget Reform across Agencies'. Katholieke Universiteit Leuven-Public Management Institute, Leuven.

Van Wart, M. 1998. Changing Public Sector Values. New York: Garland Publishing. 
Van Wart, M. and E.M. Berman. 1999. 'Contemporary Public Sector Productivity Values', Public Productivity and Management Review, 22, 3, 326-48.

Van Wart, M. and K.G. Denhardt. 2001. 'Organizational Structure: a Reflection of Society's Values and a Context for Individual Ethics', in T.L. Cooper (ed.), 2nd edn, Handbook of Administrative Ethics. New York: Marcel Dekker, pp. 227-42.

Verweij, M. forthcoming. Clumsy Solutions for a Complex World. Manuscript in Progress.

Victor, B. and J.B. Cullen. 1987. 'A Theory and Measure of Ethical Climate in Organizations', Research in Corporate Social Performance and Policy, 9, 51-71.

Victor, B. and J.B. Cullen. 1988. 'The Organizational Bases of Ethical Work Climates', Administrative Science Quarterly, 33, 1, 101-25.

Vidaver-Cohen, D. 1998. 'Moral Climate in Business Firms: a Conceptual Framework for Analysis and Change', Journal of Business Ethics, 17, 1211-26.

Yesilkagit, A.K. and J. de Vries. 2002. 'The Unanticipated Consequences of Decentralisation and Reinvention: the Province of South Holland', International Journal of Administrative Sciences, 68, 4, 579-97.

Yin, R.K. 1994. Case Study Research. Design and Methods, 2nd edn. Thousand Oaks, CA: Sage.

Zajac, G. 1996. 'Beyond Hammurabi: a Public Service Definition of Ethics Failure', Journal of Public Administration Research and Theory, 6, 4, 145-60.

Date received 10 November 2002. Date accepted 21 August 2003. 
